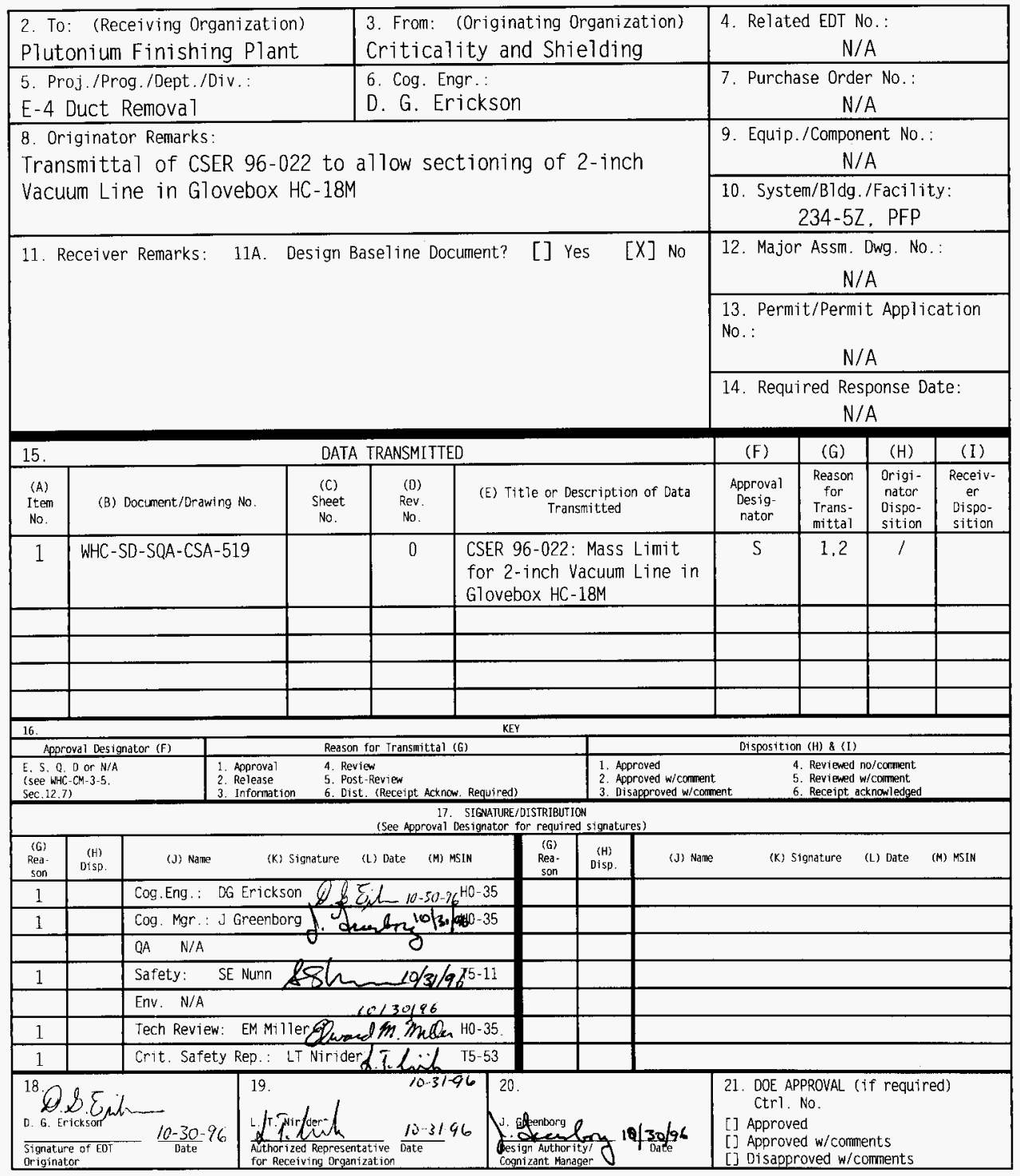

BD-7400-172-2 (05/96) GEF097 


\section{CSER 96-022: Mass Limit for 2-inch Vacuum Line in Glovebox HC-18M}

David G. Erickson

Fluor Daniel Northwest, Inc., Richland, WA 99352

U.S. Department of Energy Contract DE-AC06-96RL13200

EDT/ECN: 619218

Org Code: 403

B\&R Code: EW7003000
UC: 507

Charge Code: K6058

Total Pages: 6

Key Words: 2-inch Vacuum Line, Criticality, Glovebox HC-18M

Abstract: This Criticality Safety Evaluation Report analyzes the criticality safety of transporting and sectioning a 2.5 meter ( 8 foot) section of $5.08 \mathrm{~cm}$ (2-inch) vacuum tubing with approximately $3.8 \mathrm{~kg}$ of $\mathrm{PuO}_{2}$ via the $\mathrm{HC}-1$ conveyor and $\mathrm{HC}-18 \mathrm{M}$ glovebox in the 234-5Z building.

TRADEMARK DISCLAIMER. Reference herein to any specific commercial product, process, or service by trade name, trademark, manufacturer, or otherwise, does not necessarily constitute or imply its endorsement, recommendation, or favoring by the United States Government or any agency thereof or its contractors or subcontractors.

Printed in the United States of America. To obtain copies of this document, contact: WHC/BCS Document Control Services, P.O. Box 1970. Mailstop H6-08, Richland WA 99352. Phone (509) 372-2420; Fax (509) 376-4989.
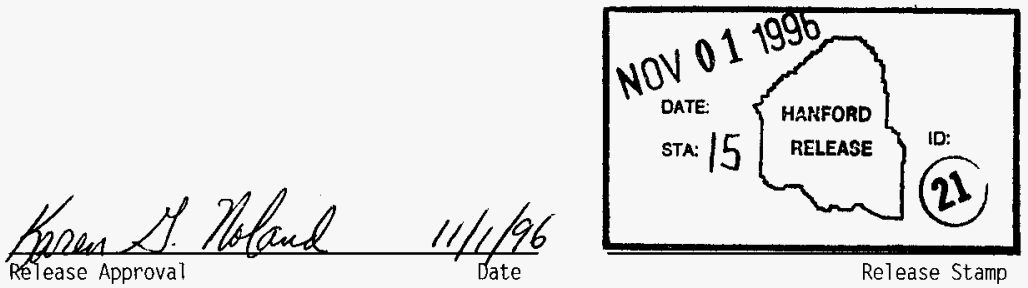

\section{Approved for Public Release}




\section{CSER-96-022}

Title: CSER 96-022: Mass Limit for 2-inch Vacuum Line in Glovebox HC-18M

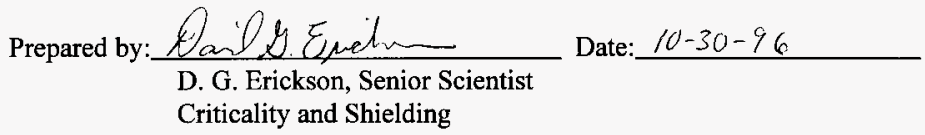

Reviewed by: Qheand Mh. Thulen Date:10-30-96

E. M. Miller, Senior Engineer

Criticality and Shielding

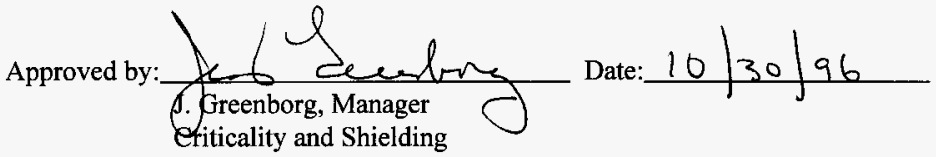

\subsection{INTRODUCTION AND SUMMARY}

The plutonium source term reduction project for building $234-5 \mathrm{Z}$ involves removing several sections of glovebox vacuum tubing containing plutonium deposits. A section of tubing with a nominal inside diameter of $5.08 \mathrm{~cm}$ and approximately $2.46 \mathrm{~m}$ in length needs to be moved via the glovebox $\mathrm{HC}-1$ conveyor to glovebox $\mathrm{HC}-18 \mathrm{M}$ for sectioning and disposal. Using NDA methods, it has been found that this section of tubing has a maximum estimated inventory of $3.8 \mathrm{~kg}$ of plutonium. Current limits will not allow batches with this much plutonium to be placed into the requested glovebox. The purpose of this criticality safety evaluation report (CSER) is to modify these limits to allow this one-time operation of moving the tubing to and thru conveyor $\mathrm{HC}-1$, sectioning this piece of tubing in glovebox HC-18M, and transferring its plutonium contents to 0.5 liter polyjars or slip-lid cans.

This analysis, shows that the proposed operation is safe from a criticality standpoint. Due to the tubing dimensions, polyjar or slip-lid can volume and plutonium compound involved, a criticality is not possible. Only a new limit on mass is needed for this specific operation. All current limits and/or controls regarding batches, spacings, water entry prevention, and use of plastics in the transfer in the HC-1 conveyor and HC-18M glovebox shall be followed. The current controls can be found in CPSs: CPS-Z-165-80608, CPS-Z-165-80620, and CPS-Z-165-80635. 
WHC-SD-SQA-CSA-519 Rev. 0

\subsection{DESCRIPTION OF PROJECT}

A straight section of tubing with a nominal inside diameter of $5.08 \mathrm{~cm}(2.0 \mathrm{in}$.) and approximately $2.46 \mathrm{~m}(8.08 \mathrm{ft}$.) in length has been found, using NDA methods, to contain a maximum estimated inventory of $3.8 \mathrm{~kg}$ of plutonium. An attempt was made to section and dispose of this tubing in place, but it was found that the risk of contamination to personnel was too great to do this outside of a glovebox. Therefore this section of tubing needs to be moved via the glovebox HC-1 conveyor to glovebox HC-18M for sectioning and disposal.

The section of tubing is currently located in room $228 \mathrm{~A}$ of the $234-5 \mathrm{Z}$ building, has its ends sealed, is double bagged, and has no appreciable moisture in it. The tubing will be moved to and bagged into the $\mathrm{HC}-1$ conveyor via a gloveport at the head end of $\mathrm{HC}-1$ in room 228A. The tubing will then travel along the conveyor to room $228 \mathrm{C}$ where glovebox $\mathrm{HC}-18 \mathrm{M}$ is located. Once in the glovebox it will be cut into shorter pieces using a band saw. The shorter lengths of tubing will be cleaned out. The material removed from inside the tubing will be placed into 0.5 liter polyjars or slip-lid cans. The cleaned pieces of tubing will then be placed into a 55 -gallon drum in preparation for final disposal.

\subsection{PREVIOUS ANALYSIS}

SD-SQA-CSA-093 (Brown, 1988) provides the basis for criticality safety in operations involving the glovebox HC-1 conveyor (CPS-Z-165-80608, WHC, 1989) and glovebox HC-18M (CPS-Z-165-80620, WHC, 1988.) For the glovebox HC-1 conveyor, its mass and volume limits are based on the limits in the source and destination gloveboxes. Glovebox HC-18M, is currently limited to a maximum of $2.5 \mathrm{~kg}$ of plutonium in a batch.

WHC-SD-SQA-CSA-20402 Rev 0 (Miller, 1995) and WHC-SD-SQA-CSA-20407 Rev.0 (Miller, 1996) provide the basis for the current limits and controls that are implemented in CPS-Z-165-80635 (WHC, 1996.) These limits and controls are used to prevent a possible criticality due to an unfavorable accumulation of plutonium while removing the 2 -inch vacuum lines. Currently a segment of 2 -inch and smaller diameter tubing is limited to a total fissile loading of $2.5 \mathrm{~kg}$ of plutonium.

\subsection{EVALUATION OF CRITICALITY SAFETY CONTROLS}

A nominal $5.1 \mathrm{~cm}$ diameter tube is of geometrically favorable dimension for plutonium compounds such as $\mathrm{PuO}_{2}$. This means that even under conditions of optimum moderation and reflection it will still be significantly subcritical. Page III.A.7(100)-3 of ARH-600 (Carter, 1968) shows that a $5.08 \mathrm{~cm}$ (2-inch) diameter fully reflected cylinder of a $\mathrm{Pu}-\mathrm{H}_{2} \mathrm{O}$ mixture is subcritical 
until there is more than $9 \mathrm{~kg}$ of plutonium per foot and the mixture density is greater than $15.0 \mathrm{~g} / \mathrm{cc}$. This density is even greater than the theoretical density of $\mathrm{PuO}_{2}$ compounds of $11.5 \mathrm{~g} / \mathrm{cc}$

From the table in ARH-600 (Carter, 1968) on page II.C.2-1 it can be seen that the tap density of $\mathrm{PuO}_{2}$ (nitrate) has a density of $1.58 \mathrm{~g} / \mathrm{cc}$. The material in the tubing is from a $\mathrm{PuO}_{2}$ (oxilate) process and has a tap density of $0.92 \mathrm{~g} / \mathrm{cc}$. For the purposes of this evaluation the more conservative $\mathrm{PuO}_{2}$ (nitrate) tap density will be used. From this we can calculate that a $5.08 \mathrm{~cm}$ diameter tubing $2.46 \mathrm{~m}$ in length can hold a maximum of $7.89 \mathrm{~kg}$ of $\mathrm{PuO}_{2}$. Plutonium is $\sim 88.2 \%$ of $\mathrm{PuO}_{2}$ so this equals $6.96 \mathrm{~kg}$ of plutonium.

The maximum estimated mass of plutonium in the tubing from NDA measurements is $3.83 \mathrm{~kg}$. Assuming the plutonium is uniformly distributed in the tubing, this gives a plutonium mass of $0.48 \mathrm{~kg}$ per foot. This mass is about $18 \%$ of the critical mass of more than $9 \mathrm{~kg}$ of plutonium per foot. From this it can be seen that criticality is not a concern while the plutonium is in the tubing, even if optimally reflected and fully reflected.

Once the tubing is cut in shorter pieces, the plutonium will be removed from the tubing either by dumping or scraping with long handled spatulas. The removed material will then be placed into 0.5 liter polyjars or slip-lid cans. For a criticality to be possible in a single polyjar or slip-lid can, it must contain at least $5 \mathrm{~kg}$ of plutonium metal (ARH-600 page III.A.9(100)-4, (Carter, 1968)). From the above discussion using the tap density of $\mathrm{PuO}_{2}$ of $1.58 \mathrm{~g} / \mathrm{cc}$ the polyjar or slip-lid can could contain approximately 790 grams. This shows that in the polyjar or slip-lid can a criticality is not possible with these materials regardless of the degree of moderation or degree of reflection. It can therefore be clearly seen that a single half liter polyjar or slip-lid can will remain well subcritical under all credible conditions.

From the above discussion it can be seen that the operation of moving the section of $5.08 \mathrm{~cm}$ (2-inch) tubing via the $\mathrm{HC}-1$ conveyor to the $\mathrm{HC}-18 \mathrm{M}$ glovebox and then cutting the tubing into shorter lengths for cleanout and disposal is safe from a criticality standpoint. A criticality is not credible regardless of the moderation or reflection present.

\subsection{TECHNICAL PEER REVIEW}

E. M. Miller of the Criticality \& Shielding Group carried out an independent, technical review of this CSER 96-022, for which the following comments were provided.

The technical arguments for qualifying the criticality safety of transporting and processing the $2 \mathrm{in}$. vacuum line with $3.8 \mathrm{~kg}$ of plutonium in conveyor $\mathrm{HC}-1$ and glovebox HC- $18 \mathrm{M}$ were found to be sound and the quoted criticality parameters in the text and table were confirmed by review of the referenced data. 
If the conservative assumption was made that this 2 -in. tubing was actually 2 -in. schedule 5 pipe, the inside diameter would be 2.24 in. This diameter does not change the geometrically safe characterization of the pipe. The only value in the analysis that is larger is the holdup capacity of the tubing. The tubing can hold $7.4 \mathrm{~kg}$ of plutonium rather than $6.96 \mathrm{~kg}$. The subcriticality of the system is based on the diameter of the tubing being too small to allow a critical system for even the maximum theoretical density of plutonium oxide. Even if water washed all the plutonium to one end of the pipe, suspended the plutonium in the water, and the suspension filled the plastic sleeve surrounding the pipe to $3 / 4$ in., a criticality would require about $10 \mathrm{~kg}$ of plutonium. This result is based on a plutonium density of greater than $4.0 \mathrm{~g} / \mathrm{cc}$, which is conservative, and that an infinite cylinder is more than 4 times as long as its diameter (i.e. 3.74 in. $x 4>12$ in.). Figure III.A.7(100)-3 (Carter 1968) graphically shows the parameters needed for criticality in an infinite cylinder. Figures III.A.3-1 and III.A.9(100)-4 show that for a 4-in diameter sphere $(0.49 \ell)$, criticality is possible only for a plutonium density greater than the theoretical maximum density of plutonium oxide, $10.96 \mathrm{~g} / \mathrm{cc}$. Further, only about $3.8 \mathrm{~kg}$ of plutonium is available in the tube while $7.5 \mathrm{~kg}$ at a minimum is needed at a density greater than is possible for plutonium oxide. So even for water entry and aggregation inside the plastic sleeve, criticality is not possible. The requirement for taping the plastic sleeve per the facility general CPS is required.

The tubing itself is geometrically safe alone. However, spacing per existing analyses (Miller 1995, 1996) is necessary between the tubing and other fissile material in transport to the conveyor, $\mathrm{HC}-1$, in the conveyor, and in glovebox $\mathrm{HC}-18 \mathrm{M}$.

Once the tube is cut and fissile material is put in containers, criticality becomes possible with the accidental addition of water, so the spacing required by previous analyses (Miller 1995, 1996) is crucial as is the specification to prevent water entry to maintaining criticality safety margins. In addition, any plutonium spills greater than $1 / 16$ in. depth should be cleaned up after completing work on the cut off tubing segment being processed.

This CSER adequately analyzes the criticality hazards of processing the 2 -in. vacuum line with less than $4 \mathrm{~kg}$ of $\mathrm{PuO}_{2}$. The $\mathrm{PuO}_{2}$ density for oxalate converted to oxide at room temperature is conservative. Contingencies have been adequately analyzed. Based on the limits of the referenced CPSs and those invoked in this CSER, the processing of the 2-in. vacuum line can be carried out within criticality allowables.

\subsection{REFERENCES}

Brown, C. L., 1988, CSAR 81-007, Add 5, Restructuring of CPS-Z-I65-80170, F-0;

$C P S-Z-80350, B-1$; CPS-Z-165-80501, $A-0$; and CPS-Z-165-80502, $A-0$,

SD-SQA-CSA-093, Rev.0, Westinghouse Hanford Company, Richland, Washington.

Carter, R. D., G. R. Kiel, and K. R. Ridgway, 1968, Criticality Handbook, ARH-600, 1980 Revision, Atlantic Richfield Hanford Company, Richland, Washington. 
Miller, E. M., 1995, CSER 95-013; Criticality Safety Limits for PFP E-4 Duct Removal, WHC-SD-SQA-CSA-20402, Rev 0, Westinghouse Hanford Company, Richland, Washington.

Miller, E. M., 1996, Addendum I to CSER 95-013; Revised PFP E-4 Duct Removal Criticality Limits for Downcomers, ALARA Shielding, NDAed Segments, and 6-Inch and Smaller Piping. WHC-SD-SQA-CSA-20407, Rev. 0, Westinghouse Hanford Company, Richland, Washington.

WHC-88, Glovebox HC-18M: Maintenance, CPS-Z-165-80620, Rev./Mod. A-0, Westinghouse Hanford Company, Richland Washington.

WHC 89, Gloveboxes HC-1 and HC-2: Conveyors, CPS-Z-165-80608, Rev./Mod. A-1, Westinghouse Hanford Company, Richland Washington.

WHC-96, 2-Inch Vacuum Line Removal, CPS-Z-165-80635, Rev./Mod. A-1, Westinghouse Hanford Company, Richland Washington. 


\section{DISTRIBUTION SHEET}

\begin{tabular}{|c|c|c|c|c|c|}
\hline \multirow{2}{*}{$\begin{array}{l}\text { To } \\
\text { Distribution }\end{array}$} & \multirow{2}{*}{\multicolumn{2}{|c|}{$\begin{array}{l}\text { From } \\
\text { Criticality and Shielding }\end{array}$}} & \multicolumn{3}{|c|}{ Page 1 of 1} \\
\hline & & & \multicolumn{3}{|c|}{ Date $10 / 31 / 96$} \\
\hline \multirow{2}{*}{\multicolumn{3}{|c|}{$\begin{array}{l}\text { Project Title/Work Order } \\
\text { CSER-022: Mass Limit for 2-inch Vacuum Line in } \\
\text { Glovebox HC-18M }\end{array}$}} & \multicolumn{3}{|c|}{ EDT No. 619218} \\
\hline & & & \multicolumn{3}{|c|}{ ECN No. N/A } \\
\hline \multicolumn{2}{|c|}{ Name } & $\begin{array}{l}\text { Text } \\
\text { With All } \\
\text { Attach. }\end{array}$ & $\begin{array}{l}\text { Text } \\
\text { Only }\end{array}$ & $\begin{array}{l}\text { Attach.l } \\
\text { Appendix } \\
\text { Only }\end{array}$ & $\begin{array}{c}\text { EDT/ECN } \\
\text { Only }\end{array}$ \\
\hline
\end{tabular}

G. B. Chronister

T5-02 $X$

D. G. Erickson (2 Copies) H0-35 $X$

J. Greenborg H0-35 $X$

S. G. Hodge T5-50 $X$

C. M. Kronvall T5-15 X

E. M. Miller HO-35 X

L. T. Nirider T5-53 $X$

S. E. Nunn T5-11 $X$

L. L. Pedersen H0-35 $X$

L. H. Rodgers T5-54 $\quad x$

Central Files (Original +2) A3. $88+8-04$ 140-35 $x$

Docket Files (2 Copies)

$140-35 x$

